\title{
Effect of Simulated Acid Rain on Potential Carbon and Nitrogen Mineralization in Forest Soils ${ }^{* 1}$
}

\author{
OUYANG Xue-Jun ${ }^{1,2}$, ZHOU Guo-Yi ${ }^{1, * 2}$, HUANG Zhong-Liang ${ }^{1}$, LIU Ju-Xiu ${ }^{1}$, ZHANG De-Qiang ${ }^{1}$ \\ and LI Jiong ${ }^{1}$ \\ ${ }^{1}$ South China Botanic Garden, Chinese Academy of Sciences, Guangzhou 510650 (China). E-mail: ouyxj@scib.ac.cn \\ ${ }^{2}$ Graduate School of the Chinese Academy of Sciences, Beijing 100049 (China)
}

(Received December 12, 2007; revised May 19, 2008)

\begin{abstract}
Acid rain is a serious environmental problem worldwide. In this study, a pot experiment using forest soils planted with the seedlings of four woody species was performed with weekly treatments of $\mathrm{pH} 4.40,4.00,3.52$, and 3.05 simulated acid rain (SAR) for 42 months compared to a control of $\mathrm{pH} 5.00$ lake water. The cumulative amounts of $\mathrm{C}$ and $\mathrm{N}$ mineralization in the five treated soils were determined after incubation at $25^{\circ} \mathrm{C}$ for $65 \mathrm{~d}$ to examine the effects of SAR treatments. For all five treatments, cumulative $\mathrm{CO}_{2}$-C production ranged from 20.24 to $27.81 \mathrm{mg} \mathrm{kg}^{-1}$ dry soil, net production of available $\mathrm{N}$ from 17.37 to $48.95 \mathrm{mg} \mathrm{kg}^{-1}$ dry soil, and net production of $\mathrm{NO}_{3}^{-}-\mathrm{N}$ from 9.09 to $46.23 \mathrm{mg} \mathrm{kg}^{-1}$ dry soil. SAR treatments generally enhanced the emission of $\mathrm{CO}_{2}-\mathrm{C}$ from the soils; however, SAR with pH 3.05 inhibited the emission. SAR treatments decreased the net production of available $\mathrm{N}$ and $\mathrm{NO}_{3}-\mathrm{N}$. The cumulative $\mathrm{CH}_{4}$ and $\mathrm{N}_{2} \mathrm{O}$ productions from the soils increased with increasing amount of simulated acid rain. The cumulative $\mathrm{CO}_{2}$ - $\mathrm{C}$ production and the net production of available $\mathrm{N}$ of the soil under Acmena acuminatissima were significantly higher $(P \leq 0.05)$ than those under Schima superba and Cryptocarya concinna. The mineralization of soil organic C was related to the contents of soil organic $\mathrm{C}$ and $\mathrm{N}$, but was not related to soil $\mathrm{pH}$. However, the overall effect of acid rain on the storage of soil organic matter and the cycling of important nutrients depended on the amount of acid deposition and the types of forests.
\end{abstract}

Key Words: forest soils, mineralization, organic C, organic N, simulated acid rain

Citation: Ouyang, X. J., Zhou, G. Y., Huang, Z. L., Liu, J. X., Zhang, D. Q. and Li, J. 2008. Effect of simulated acid rain on potential carbon and nitrogen mineralization in forest soils. Pedosphere. 18(4): 503-514.

\section{INTRODUCTION}

Mineralization processes of soil organic $\mathrm{C}$ and $\mathrm{N}$ are important in regulating the cycling of nutrients in ecosystems and global carbon circulation (Tiessen et al., 1994; Johnson, 1995; Lal, 2001). Many geographic factors and soil properties, such as moisture, temperature, texture, inorganic nutrient supply, and pH, affect the mineralization processes (Weier and Gilliam, 1986; Motavalli et al., 1995; Šimek et al., 2002). Accurate modeling of soil $\mathrm{C}$ and $\mathrm{N}$ mineralization and their responses to the changes in environment requires a detailed understanding of the factors that control or influence these biogeochemical processes. Since the last century, acid deposition, as an important threat to many ecosystems (Karajick, 2001), has been studied worldwide (Seip et al., 1999; Streets et al., 1999; Rodhe et al., 1992; Kato, 1996; Hettelingh et al., 1995; Lacaux et al., 1987; Cogbill and Likens, 1974). Field and laboratory observations show that acid deposition decreases soil $\mathrm{pH}$, increases nutrient loss (Makarov and Kiseleva, 1995) and heavy element activation (Derome and Lindroos, 1998; Michopoulos, 1999), and alters microbial community structure (Pennanen et al., 1998; Pennanen, 2001). Despite chronic N deposition that reduces soil respiration (Burton et al., 2004) and suppresses the mineralization of native C (Hagedorn

\footnotetext{
${ }^{* 1}$ Project supported by the Knowledge Innovation Program of the Chinese Academy of Sciences (No. KSCX2-SW-120) and the National Natural Science Foundation of China (No. 30470306).

${ }^{* 2}$ Corresponding author. E-mail: gyzhou@scib.ac.cn.
} 
et al., 2001), the effect of acid deposition on the mineralization of soil organic $\mathrm{C}$ and $\mathrm{N}$ has not been fully explored.

The mineralization of soil organic matter (SOM) is an essential biological process. Acid deposition might directly affect the mineralization of SOM by changing microbial activity (Zelles et al., 1987; Blagodatskaya and Anderson, 1999), enzyme activity (Haynes and Swift, 1988; Shah et al., 1990), and the composition of the microbial population (Shah et al., 1990; Nodar et al., 1992; Pennanen et al., 1998; Pennanen, 2001; Bååth and Anderson, 2003). Although there are studies on the effect of acid deposition on microbial biomass C, results from those studies are inconsistent. For example, Blagodatskaya and Anderson (1999) found that the extent of microbial biomass $\mathrm{C}$ decrease or $\mathrm{CO}_{2}$ increase corresponded with the amount of initial $\mathrm{H}^{+}$ions input. In contrast, Pennanen et al. (1998) indicated that treatments of simulated acid rain alone or combined with heavy metals did not affect total microbial biomass. This might be because a bacterial community can adapt to its new environmental conditions, such as more acidic conditions, or the microbial biomass can be re-established with time (Blagodatskaya and Anderson, 1999; Pennanen et al., 1998).

By decreasing soil $\mathrm{pH}$, acid deposition might indirectly influence the content and mineralization of SOM because soil $\mathrm{pH}$ has a significant effect on the formation and mineralization of SOM (van Bergen et al., 1998; Nierop and Vertraten, 2003; Motavalli et al., 1995; Ellis et al., 1998). However, results of existing studies with regard to the effect of soil $\mathrm{pH}$ on $\mathrm{SOM}$ are often conflicting. For example, the mineralization of $\mathrm{C}$ increased with soil liming and decreased after acidification (Motavalli et al., 1995; Chandini et al., 1996; Ellis et al., 1998). The negative correlation between soil organic C and soil pH (Spain, 1990) implied that the decrease of soil $\mathrm{pH}$ promoted an increase in SOM. However, in cottonwood stands, Lee and Jose (2003) observed a negative correlation between annual soil respiration rates and soil $\mathrm{pH}$. The total microbial biomass estimated by substrate-induced respiration (SIR) and phospholipid fatty acid (PLFA) technique was positively correlated to soil pH (Bååth and Anderson, 2003). This partially supports the hypothesis by Oades (1988) who predicted shorter C turnover times in acidic soils compared with calcareous soils. The fact that there is no definite answer to the effect of soil pH on mineralization of SOM (van Bergen et al., 1998; Motavalli et al., 1995) suggests that factors besides soil pH must be important and should be considered (Oades, 1988; Nierop and Vertraten, 2003).

The mineralization of SOM might be indirectly affected by acid deposition, which decreases nutrient supply (Cleveland et al., 2002) and increases biologically toxic cations such as $\mathrm{Al}^{3+}$ (Berggren and Mulder, 1995; Beets et al., 2002; Schwesig et al., 2003). However, direct tests of this hypothesis have not been found in the literature so far. The objectives of this study were to compare the mineralization of organic $\mathrm{C}$ and $\mathrm{N}$ in soils treated with simulated acid rain and to identify how simulated acid rain influences the potential mineralization in different forest ecosystems.

\section{MATERIALS AND METHODS}

Site description

This study was conducted in the Dinghushan Biosphere Reserve (DHSBR), which lies in central Guangdong Province $\left(23^{\circ} 10^{\prime} \mathrm{N}\right.$ and $\left.112^{\circ} 34^{\prime} \mathrm{E}\right)$, southern China. The reserve has a monsoon climate and is in a subtropical moist forest zone. The mean annual rainfall of $1927 \mathrm{~mm}$ has a distinct seasonal pattern with $75 \%$ of it falling from March to August and only $6 \%$ from December to February (Huang and Fan, 1982). The average annual relative humidity is $80 \%$; mean annual temperature is $21.0^{\circ} \mathrm{C}$ with the highest average monthly temperature of $28.0^{\circ} \mathrm{C}$ in July and the lowest average monthly temperature of $12.6^{\circ} \mathrm{C}$ in January.

Two forest sites were selected for this study. One is a monsoon evergreen broadleaf forest at about 250-300 m above sea level (ASL), which occupies about 600 ha and has been protected from human interference for more than 400 years by monks in a local temple (Zhou et al., 1986). The major species of this forest are Castanopsis chinensis Hance, Schima superba Gardn. et Champ., Cryptocarya chinensis 
(Hance) Hemsl., Cryptocarya concinna Hance, Acmena acuminatissima (Bl.) Merr. et Perry, and Machilus chinensis (Champ. ex Benth.) Hemsl. in the crown layer, and Calamus rhabdocladus Burret, Ardisia quinquegona Bl., and Hemigramma decurrens (Hook.) Copel. in the understory, with tree heights ranging from 4 to $30 \mathrm{~m}$ and diameters from 5 to $163 \mathrm{~cm}$ (Wang et al., 1982). The other is a pine forest planted in about 1930 at about 50-200 m ASL, which occupies 600 ha (Wang et al., 1982), and is dominated by Pinus massoniana Lamb. The pine stand density ranges from 100 to 1000 trees ha $^{-1}$ with diameter ranging from 4 to $32 \mathrm{~cm}$, heights from 3 to $11 \mathrm{~m}$, and ages from 12 to 69 years. Understory species include grasses, ferns, vines, and shrubs, totaling 43 species (Brown et al., 1995). The soil types of these two forests are acidic Latosols derived from sandstone. In the monsoon evergreen broadleaf forest, the depth of soil layer is more than $60 \mathrm{~cm}$, but the soil depth under the pine forest is generally less than $30 \mathrm{~cm}$. Some selected soil properties of these two forests are listed in Table I.

TABLE I

Some soil properties $(0-10 \mathrm{~cm}$ depth) of the two forest sites selected

\begin{tabular}{lll}
\hline Property & Monsoon evergreen broadleaf forest & Pine forest \\
\hline Organic matter $\left(\mathrm{g} \mathrm{kg}^{-1}\right)$ & $72.4 \pm 7.4$ & $36.7 \pm 1.4$ \\
Total N $\left(\mathrm{g} \mathrm{kg}^{-1}\right)$ & $2.5 \pm 0.2$ & $1.1 \pm 0.1$ \\
Total C/N ratio & $16.81 \pm 0.70$ & $19.01 \pm 0.80$ \\
$\mathrm{NO}_{3}^{-}\left(\mathrm{mg} \mathrm{kg}^{-1}\right)$ & $66.14 \pm 1.2$ & $59.86 \pm 34.3$ \\
$\mathrm{SO}_{4}^{2-}\left(\mathrm{mg} \mathrm{kg}^{-1}\right)$ & $9.28 \pm 1.3$ & $7.18 \pm 1.2$ \\
Exchangeable K$\left(\mathrm{mg} \mathrm{kg}^{-1}\right)$ & $67.41 \pm 0.4$ & $45.11 \pm 10.0$ \\
Exchangeable Na $\left(\mathrm{mg} \mathrm{kg}^{-1}\right)$ & $11.94 \pm 0.2$ & $15.79 \pm 7.1$ \\
Exchangeable $1 / 2 \mathrm{Ca}^{2+}\left(\mathrm{mg} \mathrm{kg}^{-1}\right)$ & $434.16 \pm 10.2$ & $599.5 \pm 82.8$ \\
Exchangeable $1 / 2 \mathrm{Mg}^{2+}\left(\mathrm{mg} \mathrm{kg}^{-1}\right)$ & $62.35 \pm 0.0$ & $63.15 \pm 11.8$ \\
Available P $\left(\mathrm{mg} \mathrm{kg}^{-1}\right)$ & $4.48 \pm 0.0$ & $3.74 \pm 0.4$ \\
Available Fe $\left(\mathrm{mg} \mathrm{kg}^{-1}\right)$ & $168.08 \pm 5.3$ & $92.83 \pm 14.1$ \\
Activate Al $\left(\mathrm{mg} \mathrm{kg}^{-1}\right)$ & $1635 \pm 12.3$ & $986.8 \pm 89.3$ \\
pH $(\mathrm{KCl})$ & $3.22 \pm 0.0$ & $3.38 \pm 0.1$ \\
\hline
\end{tabular}

a) Data for organic matter, total $\mathrm{N}$, and total $\mathrm{C} / \mathrm{N}$ ratio are obtained from Mo et al. (2003).

\section{Pot experiment}

In September 2000, soil samples $(0-10 \mathrm{~cm})$ were randomly collected from the two forests and mixed. Pots containing approximately $6 \mathrm{~kg}$ of the mixed soil samples of the broadleaf soil or the pine soil were planted with two-year-old seedlings of A. acuminatissima, S. superba, and C. concinna from the broadleaf forest or $P$. massoniana from the pine forest, respectively. All the pots were placed in an open area in the DHSBR. After one month, a total of 80 pots with the four species, 20 pots with the same species, were selected and divided into five groups. There were four species and 16 seedlings in each group.

From December 2000 to April 2004, the pots in the same group were treated with $800 \mathrm{~mL}$ of local lake water (control, CK, about $\mathrm{pH} 5.00$ ) and simulated acid rain (SAR) of $\mathrm{pH} 4.40,4.00,3.52$, and 3.05 weekly for 42 months. Simulated acid rain was prepared by mixing the lake water with a stock acid solution consisting of $\mathrm{H}_{2} \mathrm{SO}_{4}$ and $\mathrm{HNO}_{3}$ (1:1 mole ratio). The accumulative $\mathrm{S}$ and $\mathrm{N}$ deposition from the 42-month experiment with SAR of $\mathrm{pH} 4.40,4.00,3.52$, and 3.05 was equivalent to $\mathrm{S}$ deposition of 3.5, 7,25 , and 70 years and $\mathrm{N}$ deposition of $7,21,60$, and 174 years, respectively, of natural precipitation in the area.

Sampling, incubation, and measurements

About $400 \mathrm{~g}$ soil samples were collected from each of the pots on April 20, 2004. Soil samples were sieved through a 2-mm sieve immediately after collection to remove coarse roots and stones, and then they were thoroughly mixed. The sieved soil sample was divided into two portions. One was air dried 
for measuring the soil properties, and the other was incubated for measuring active carbon, $\mathrm{NH}_{4}^{+}-\mathrm{N}$, and $\mathrm{NO}_{3}^{-}-\mathrm{N}$.

Moist soil (equivalent to $50 \mathrm{~g}$ oven-dried soil) was weighed into a $100-\mathrm{mL}$ polypropylene beaker and adjusted to $60 \%$ water holding capacity (WHC), and then the beakers were placed in $1200-\mathrm{mL}$ PVC containers together with another 100-mL beaker containing $10 \mathrm{~mL}$ distilled water to maintain air humidity in the incubation chamber. The PVC containers were sealed with polyethylene film and then placed in a dark room at $25{ }^{\circ} \mathrm{C}$. The headspace of the PVC containers was sampled for $\mathrm{CO}_{2}, \mathrm{CH}_{4}$, and $\mathrm{N}_{2} \mathrm{O}$ at 5,12, 20,30,45, and $65 \mathrm{~d}$ using medical gastight syringes. The film of the PVC container and the window of the room were opened and fanned for approximately $2 \mathrm{~h}$ at each sampling to prevent anoxia in the container. During the incubation, water content was checked at 12,30 , and $45 \mathrm{~d}$, and distilled water was added if necessary to adjust the beakers to their original weights. After $65 \mathrm{~d}$ of incubation, the soil in the beakers was sampled to quantify $\mathrm{NH}_{4}^{+}-\mathrm{N}$ and $\mathrm{NO}_{3}^{-}-\mathrm{N}$. Eight blanks (no soil) were used to estimate background $\mathrm{CO}_{2}, \mathrm{CH}_{4}$, and $\mathrm{N}_{2} \mathrm{O}$ productions.

The active carbon was measured with the colorimetric method after the soil $\mathrm{C}$ was oxidized by 0.02 mol L${ }^{-1}$ alkaline $\mathrm{KMnO}_{4}$ (Weil et al., 2003). The $\mathrm{NH}_{4}^{+}-\mathrm{N}$ and $\mathrm{NO}_{3}^{-}-\mathrm{N}$ were extracted with 50 $\mathrm{mL} 2 \mathrm{~mol} \mathrm{~L}^{-1} \mathrm{KCl}$ (soil:extractant $=1: 5$ ) by shaking on an end-to-end shaker $\left(160 \mathrm{r} \mathrm{min}^{-1}\right.$ ) for $1 \mathrm{~h}$, followed by filtration through filter paper. $\mathrm{NH}_{4}^{+}-\mathrm{N}$ was determined using the indophenol blue method, and $\mathrm{NO}_{3}^{-}-\mathrm{N}$ was determined using the cadmium reduction method (Liu, 1996). Soil $\mathrm{pH}$ was determined in a 1:2.5 soil-to- $\mathrm{KCl}$ suspension $\left(1 \mathrm{~mol} \mathrm{~L}^{-1}\right)$. The available $\mathrm{N}$ was defined as the sum of $\mathrm{NH}_{4}^{+}-\mathrm{N}$ and $\mathrm{NO}_{3}^{-}-\mathrm{N}$. Organic $\mathrm{C}$ and total $\mathrm{N}$ were measured using the wet acid dichromate oxidation and semi-micro Kjeldahl methods, respectively (Liu, 1996). The concentrations of $\mathrm{CO}_{2}, \mathrm{CH}_{4}$, and $\mathrm{N}_{2} \mathrm{O}$ in each syringe were immediately determined after sampling using a gas chromatograph (Agilent HP4890D, USA) with pure $\mathrm{N}_{2}$ as a carrier gas. The measured $\mathrm{CO}_{2}\left(\mu \mathrm{L} \mathrm{L}^{-1}\right), \mathrm{CH}_{4}\left(\mu \mathrm{L} \mathrm{L}^{-1}\right)$, and $\mathrm{N}_{2} \mathrm{O}\left(\times 10^{-3} \mu \mathrm{L} \mathrm{L}^{-1}\right)$ concentrations of each sample were used to calculate the amount of evolved $\mathrm{CO}_{2}-\mathrm{C}\left(\mathrm{mg} \mathrm{kg}^{-1}\right.$ dry soil), $\mathrm{CH}_{4}\left(\mu \mathrm{g} \mathrm{kg}^{-1}\right.$ dry soil), and $\mathrm{N}_{2} \mathrm{O}\left(\mu \mathrm{g} \mathrm{kg}^{-1}\right.$ dry soil) based on the PVC container headspace volume and the soil dry weight in the beaker. The factors to convert $\mu \mathrm{L} \mathrm{CO}_{2}-\mathrm{C}, \mathrm{N}_{2} \mathrm{O}$, and $\mathrm{CH}_{4}$ into $\mu \mathrm{g} \mathrm{CO}_{2}-\mathrm{C}$, $\mathrm{N}_{2} \mathrm{O}$, and $\mathrm{CH}_{4}$ were $1.80,1.80$, and 0.65 , respectively, assuming a mole volume of 22.4 for $\mathrm{CO}_{2}, \mathrm{~N}_{2} \mathrm{O}$, and $\mathrm{CH}_{4}$ at $25{ }^{\circ} \mathrm{C}$ under pressure of $1.013 \mathrm{kPa}$. All concentrations in the soil were expressed on the basis of an oven-dry weight $\left(105^{\circ} \mathrm{C}\right)$.

\section{Statistical analyses}

Differences in soil properties and cumulative gas production between treatments and between species were tested with a one-way analysis of variance (ANOVA). When the treatment and species effects were found to be significant $(P \leq 0.05)$, the least significant difference (LSD) or Games-Howell multiple range test was used to assess the differences. Correlation analysis was used to determine the relationship between soil properties and cumulative gas production as well as 65 day $\mathrm{N}$ production for significance at $P \leq 0.05$. All the analyses were performed using the SPSS software version 11.0.

\section{RESULTS}

\section{Soil properties after simulated acid rain treatment}

Soil organic $\mathrm{C}$ and total $\mathrm{N}$ were maximum for the treatment with SAR of $\mathrm{pH} 4.00$ after 42 months of experiment (Table II). The only significant difference in soil total $\mathrm{N}$ appeared between the control and $\mathrm{pH} 4.00(P \leq 0.05)$, and no significant differences in soil organic $\mathrm{C}$ were found for all the treatments. Soil $\mathrm{NH}_{4}^{+}$-N of the treatment with SAR of $\mathrm{pH} 3.05$ was significantly higher compared with all other treatments, and $\mathrm{NO}_{3}^{-}-\mathrm{N}$ in the control ( $\mathrm{pH}$ 5.00) was significantly higher than all other treatments $(P \leq 0.05)$ (Table II). Available $\mathrm{N}\left(\mathrm{NH}_{4}^{+}-\mathrm{N}+\mathrm{NO}_{3}^{-}-\mathrm{N}\right)$ was significantly higher $(P \leq 0.05)$ in the control and the treatment with pH 3.05 SAR than the other treatments (Table II). The percentage of $\mathrm{NH}_{4}^{+}-\mathrm{N}$ in available $\mathrm{N}$ was $37.92 \%$ in the control, whereas it was more than $54 \%$ in the treatments with 
SAR. Furthermore, this percentage tended to increase as pH in the treatments decreased (Table II).

\section{TABLE II}

Soil carbon, nitrogen, and pH after the 42-month treatment with pH 5.00 lake water (control) and simulated acid rain (SAR) of different $\mathrm{pH}(n=16)$ and those under different seedling species $(n=20)$ from the monsoon evergreen broadleaf forest

\begin{tabular}{|c|c|c|c|c|c|}
\hline & pH 5.00 control & $\mathrm{pH} 4.40 \mathrm{SAR}$ & $\mathrm{pH} 4.00 \mathrm{SAR}$ & $\mathrm{pH} 3.52 \mathrm{SAR}$ & pH 3.05 SAR \\
\hline $\mathrm{pH}(\mathrm{KCl})$ & $3.31 \mathrm{a}^{\mathrm{a})}(0.08)^{\mathrm{b})}$ & $3.28 \mathrm{ab}(0.17)$ & $3.22 \mathrm{bc}(0.07)$ & $3.15 \mathrm{c}(0.04)$ & $2.97 \mathrm{~d}(0.09)$ \\
\hline Active $\mathrm{C}\left(\mathrm{mg} \mathrm{kg}^{-1}\right)$ & $935.5 \mathrm{a}(153.4)$ & $922.2 \mathrm{a}(160.5)$ & $897.5 \mathrm{a}(155.0)$ & $913.4 \mathrm{a}(128.1)$ & $854.5 \mathrm{a}(116.4)$ \\
\hline Organic C $\left(\mathrm{g} \mathrm{kg}^{-1}\right)$ & $20.4 \mathrm{a}(7.8)$ & $22.5 \mathrm{a}(7.7)$ & $23.2 \mathrm{a}(8.0)$ & $21.5 \mathrm{a}(7.2)$ & $18.7 \mathrm{a}(6.3)$ \\
\hline $\mathrm{NH}_{4}^{+}-\mathrm{N}\left(\mathrm{mg} \mathrm{kg}^{-1}\right)$ & $2.86 \mathrm{~b}(1.61)$ & $3.05 b(1.78)$ & $3.14 \mathrm{~b}(1.40)$ & $2.96 \mathrm{~b}(1.98)$ & $6.98 \mathrm{a}(2.75)$ \\
\hline $\mathrm{NO}_{3}^{-}-\mathrm{N}\left(\mathrm{mg} \mathrm{kg}^{-1}\right)$ & $4.65 \mathrm{a}(1.76)$ & $2.446 \mathrm{~b}(1.11)$ & $1.99 \mathrm{~b}(1.74)$ & $1.49 \mathrm{~b}(0.54)$ & $2.03 \mathrm{~b}(1.12)$ \\
\hline Available $\mathrm{N}\left(\mathrm{mg} \mathrm{kg}^{-1}\right)$ & $7.52 \mathrm{ab}(0.57)$ & $5.50 \mathrm{c}(0.52)$ & $5.13 \mathrm{c}(0.52)$ & $4.45 \mathrm{c}(0.57)$ & $9.01 \mathrm{a}(0.86)$ \\
\hline Total N $\left(\mathrm{g} \mathrm{kg}^{-1}\right)$ & $0.97 \mathrm{~b}(0.41)$ & $1.07 \mathrm{ab}(0.37)$ & $1.21 \mathrm{a}(0.35)$ & $1.12 \mathrm{ab}(0.31)$ & $1.09 \mathrm{ab}(0.26)$ \\
\hline $\mathrm{NH}_{4}^{+}-\mathrm{N}$ in available $\mathrm{N}(\%)$ & 37.92 & 54.74 & 64.84 & 64.58 & 77.13 \\
\hline Total $\mathrm{C} / \mathrm{N}$ ratio & $21.9 \mathrm{a}(3.2)$ & $21.6 \mathrm{a}(4.5)$ & $19.0 \mathrm{~b}(2.4)$ & $19.1 \mathrm{~b}(3.1)$ & $17.1 \mathrm{~b}(3.4)$ \\
\hline & \multicolumn{2}{|c|}{ Acmena acuminatissima } & \multicolumn{2}{|c|}{ Schima superba } & Cryptocarya concinna \\
\hline $\mathrm{pH}(\mathrm{KCl})$ & \multicolumn{2}{|c|}{$3.11 b(0.12)$} & \multicolumn{2}{|c|}{$3.26 \mathrm{a}(0.17)$} & $3.15 \mathrm{~b}(0.13)$ \\
\hline Active $\mathrm{C}\left(\mathrm{mg} \mathrm{kg}^{-1}\right)$ & \multicolumn{2}{|c|}{$1015.4 \mathrm{a}(81.0)$} & \multicolumn{2}{|c|}{$810.4 \mathrm{~b}(570.1)$} & $1040.0 \mathrm{a}(80.4)$ \\
\hline Organic $\mathrm{C}\left(\mathrm{g} \mathrm{kg}^{-1}\right)$ & \multicolumn{2}{|c|}{$28.1 \mathrm{a}(3.3)$} & \multicolumn{2}{|c|}{$16.4 \mathrm{~b}(3.5)$} & $27.5 \mathrm{a}(2.9)$ \\
\hline $\mathrm{NH}_{4}^{+}-\mathrm{N}\left(\mathrm{mg} \mathrm{kg}^{-1}\right)$ & \multicolumn{2}{|c|}{$3.30 \mathrm{a}(2.86)$} & \multicolumn{2}{|l|}{$3.01 \mathrm{a}(1.31)$} & $3.77 \mathrm{a}(2.71)$ \\
\hline $\mathrm{NO}_{3}^{-}-\mathrm{N}\left(\mathrm{mg} \mathrm{kg}^{-1}\right)$ & \multicolumn{2}{|c|}{$2.80 \mathrm{a}(1.92)$} & \multicolumn{2}{|l|}{$1.55 \mathrm{~b}(0.79)$} & $3.52 \mathrm{a}(1.90)$ \\
\hline Available $\mathrm{N}\left(\mathrm{mg} \mathrm{kg}^{-1}\right)$ & \multicolumn{2}{|c|}{$6.10 \mathrm{ab}(2.89)$} & \multicolumn{2}{|l|}{$4.56 \mathrm{~b}(1.40)$} & $7.29 \mathrm{a}(3.52)$ \\
\hline Total N $\left(\mathrm{g} \mathrm{kg}^{-1}\right)$ & \multicolumn{2}{|c|}{$1.37 \mathrm{a}(0.13)$} & \multicolumn{2}{|l|}{$0.92 \mathrm{~b}(0.28)$} & $1.36 \mathrm{a}(0.14)$ \\
\hline $\mathrm{NH}_{4}^{+}-\mathrm{N}$ in available $\mathrm{N}(\%)$ & \multicolumn{2}{|c|}{54.10} & \multicolumn{2}{|l|}{66.01} & \\
\hline Total $\mathrm{C} / \mathrm{N}$ ratio & $20.62 \mathrm{a}(2$. & & $18.65 \mathrm{a}(4.76$ & 20.3 & $(2.55)$ \\
\hline
\end{tabular}

a) Values in the same row (within treatments or within species) followed by the same letter(s) are not significantly different at $P \leq 0.05$ (least significant difference test or Games-Howell multiple range test).

b) Values in the parenthesis are standard deviation.

Because the soils under the A. acuminatissima, C. concinna, and S. superba seedlings were collected from the monsoon evergreen broadleaf forest before the experiment started, the effect of tree species on the mineralization of soil $\mathrm{C}$ and $\mathrm{N}$ after the 42-month experiment with acid rain could be compared. The $\mathrm{pH}$ of the soil under $S$. superba was significantly $(P \leq 0.05)$ higher than that of the soils under A. acuminatissima and $C$. concinna (Table II). The concentrations of soil active C, organic $\mathrm{C}, \mathrm{NO}_{3}^{-}-\mathrm{N}$, and total $\mathrm{N}$ under $S$. superba were significantly lower $(P \leq 0.05)$ than those under A. acuminatissima and $C$. concinna. The concentration of available $\mathrm{N}$ in the $C$. concinna soil was significantly higher $(P \leq 0.05)$ than that of the $S$. superba soil. These tree species demonstrated no significant differences for the concentration of $\mathrm{NH}_{4}^{+}-\mathrm{N}$ and total $\mathrm{C} / \mathrm{N}$ ratio.

\section{Carbon mineralization}

For all five treatments, cumulative $\mathrm{CO}_{2}-\mathrm{C}$ production at the end of the $65 \mathrm{~d}$ incubation ranged from 20.24 to $27.81 \mathrm{mg} \mathrm{kg}^{-1}$ dry soil (Fig. 1). Compared to the control with $\mathrm{pH} 5.00$ lake water, treatments with acid rain for 42 months generally enhanced the accumulation of $\mathrm{CO}_{2}$-C production; however, the cumulative $\mathrm{CO}_{2}$-C production with $\mathrm{SAR}$ of $\mathrm{pH} 3.05$ was inhibited (Fig. 1). The soil treated with $\mathrm{pH}$ 3.05 SAR throughout the incubation posed the minimum cumulative $\mathrm{CO}_{2}-\mathrm{C}$ production, which was significantly less $(P \leq 0.05)$ than those from the soils treated with $\mathrm{pH} 3.52$ and $\mathrm{pH} 4.00 \mathrm{SAR}$ except for $\mathrm{pH} 4.00$ at day 12. After $12 \mathrm{~d}$ of incubation, the cumulative $\mathrm{CO}_{2}$-C production of the control was significantly less $(P \leq 0.05)$ than that from the soil treated with $\mathrm{pH} 3.52 \mathrm{SAR}$. After $5 \mathrm{~d}$ of incubation, the soil treated with $\mathrm{pH} 3.52 \mathrm{SAR}$ demonstrated the maximum cumulative $\mathrm{CO}_{2}$-C production (Fig. 1). The cumulative $\mathrm{CO}_{2}$ - $\mathrm{C}$ production was always significantly higher $(P \leq 0.05)$ from the soils under $A$. acuminatissima than $C$. concinna. Significant differences $(P \leq 0.05)$ were also found in cumulative 
$\mathrm{CO}_{2}$-C production between $A$. acuminatissima and $S$. superba in the first $5 \mathrm{~d}$ and after $20 \mathrm{~d}$.

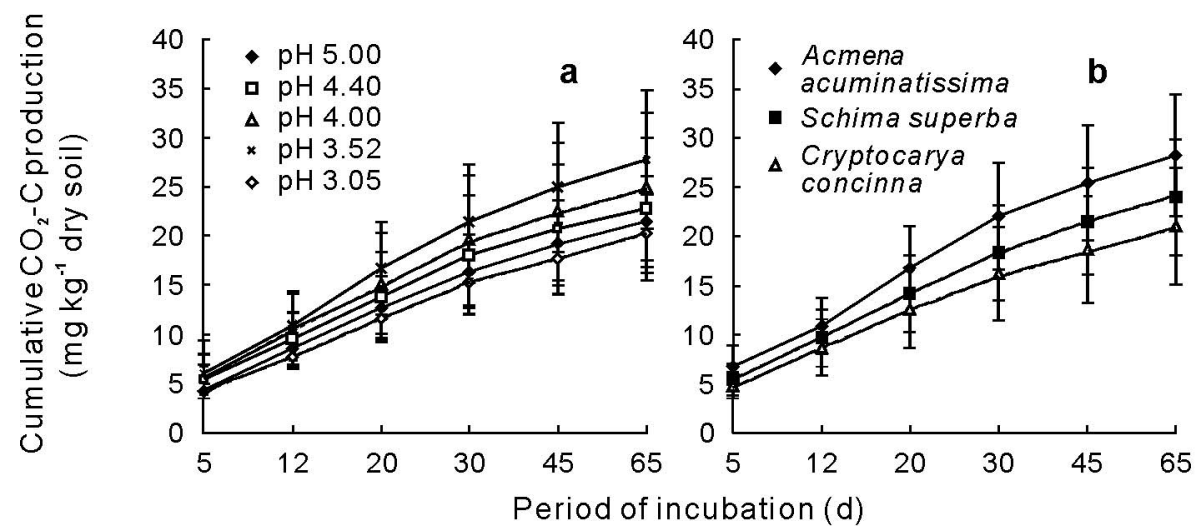

Fig. 1 Effects of simulated acid rain with different $\mathrm{pH}$ compared to the control with $\mathrm{pH} 5.00$ lake water $(n=16)(\mathrm{a})$ and wood species $(n=20)(\mathrm{b})$ on cumulative $\mathrm{CO}_{2}$ - C production during soil incubation at $25{ }^{\circ} \mathrm{C}$. Data are mean \pm standard deviation.

Cumulative $\mathrm{CH}_{4}$ production from the soil of the control was always significantly less than that from the soil treated with $\mathrm{pH} 3.05 \mathrm{SAR}(P \leq 0.05)$. After $20 \mathrm{~d}$, cumulative $\mathrm{CH}_{4}$ production from the soils treated with $\mathrm{pH} 4.40$ and $\mathrm{pH} 4.00 \mathrm{SAR}$ became lesser than that from the soil treated with $\mathrm{pH} 3.05$ SAR $(P \leq 0.05)$. The maximum cumulative $\mathrm{CH}_{4}$ was found in the control, and the minimum cumulative $\mathrm{CH}_{4}$ was found in the soil treated with pH 3.05 SAR (Fig. 2a). This pattern persisted throughout the incubation. The cumulative $\mathrm{CH}_{4}$ production tented to increase with the increasing amount of acid rain. Cumulative $\mathrm{CH}_{4}$ production from the soil under $S$. superba was always significantly higher $(P \leq 0.05)$ than those from the soils under A. acuminatissima and $C$. concinna. Cumulative $\mathrm{CH}_{4}$ of all soils except those treated with pH 3.05 SAR from 30 to $65 \mathrm{~d}$ was below zero (Fig. 2b).

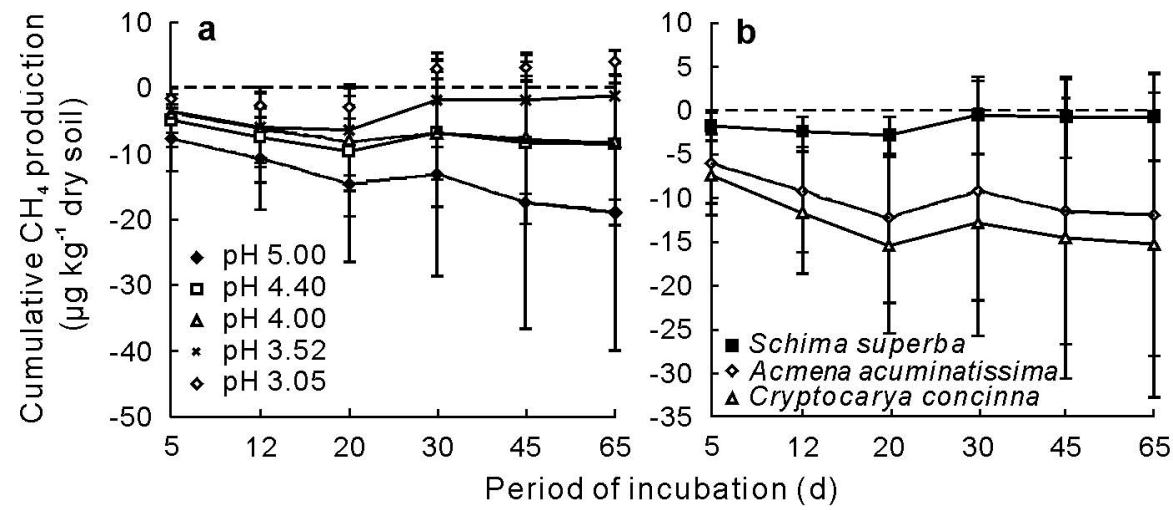

Fig. 2 Effects of simulated acid rain with different $\mathrm{pH}$ compared to the control with $\mathrm{pH} 5.00$ lake water $(n=16)(\mathrm{a})$ and wood species $(n=20)$ (b) on cumulative $\mathrm{CH}_{4}$ production during soil incubation at $25^{\circ} \mathrm{C}$. Data are mean \pm standard deviation.

\section{Nitrogen mineralization}

In the soils treated with $\mathrm{SAR}$, the net production of available $\mathrm{N}$ ranged from 17.37 to $48.95 \mathrm{mg}$ $\mathrm{kg}^{-1}$ and the net production of $\mathrm{NO}_{3}^{-}-\mathrm{N}$ ranged from 9.09 to $46.23 \mathrm{mg} \mathrm{kg}^{-1}$ with a tendency to decrease with the decrease in SAR pH (Fig. 3a). In the soils treated with $\mathrm{pH} 3.05 \mathrm{SAR}$, both net productions of available $\mathrm{N}$ and of $\mathrm{NO}_{3}^{-}-\mathrm{N}$ were significantly lower $(P \leq 0.05)$ than those in the soil of the control as well as the soils treated with $\mathrm{pH} 4.40, \mathrm{pH} 4.00$, and pH $3.52 \mathrm{SAR}$ (Fig. 3a). The percentage of net $\mathrm{NH}_{4}^{+}-\mathrm{N}$ production in the net available $\mathrm{N}$ production ranged from $4.67 \%$ to $54.07 \%$ and tended to increase with 
the decrease in SAR pH (Table III). The net production of available $\mathrm{N}$ accounted for $5.84 \%-1.62 \%$ of soil total $\mathrm{N}$, and the net production of $\mathrm{NO}_{3}^{-}-\mathrm{N}$ for $5.56 \%-0.72 \%$ (Fig. 3a). These percentages decreased with the decrease in SAR $\mathrm{pH}$. The net production of available $\mathrm{N}$ in the A. acuminatissima soil was significantly higher than those in the $S$. superba $(P \leq 0.001)$ soil and $C$. concinna $(P \leq 0.01)$ soil (Fig. 3b). Less $\mathrm{NO}_{3}^{-}$-N was released from the $S$. superba soil than the A. acuminatissima $(P \leq 0.01)$ and $C$. concinna $(P \leq 0.05)$ soils. The percentage of $\mathrm{NH}_{4}^{+}-\mathrm{N}$ in net available $\mathrm{N}$ production in the soils under A. acuminatissima, S. superba, and C. concinna are shown in Table III.

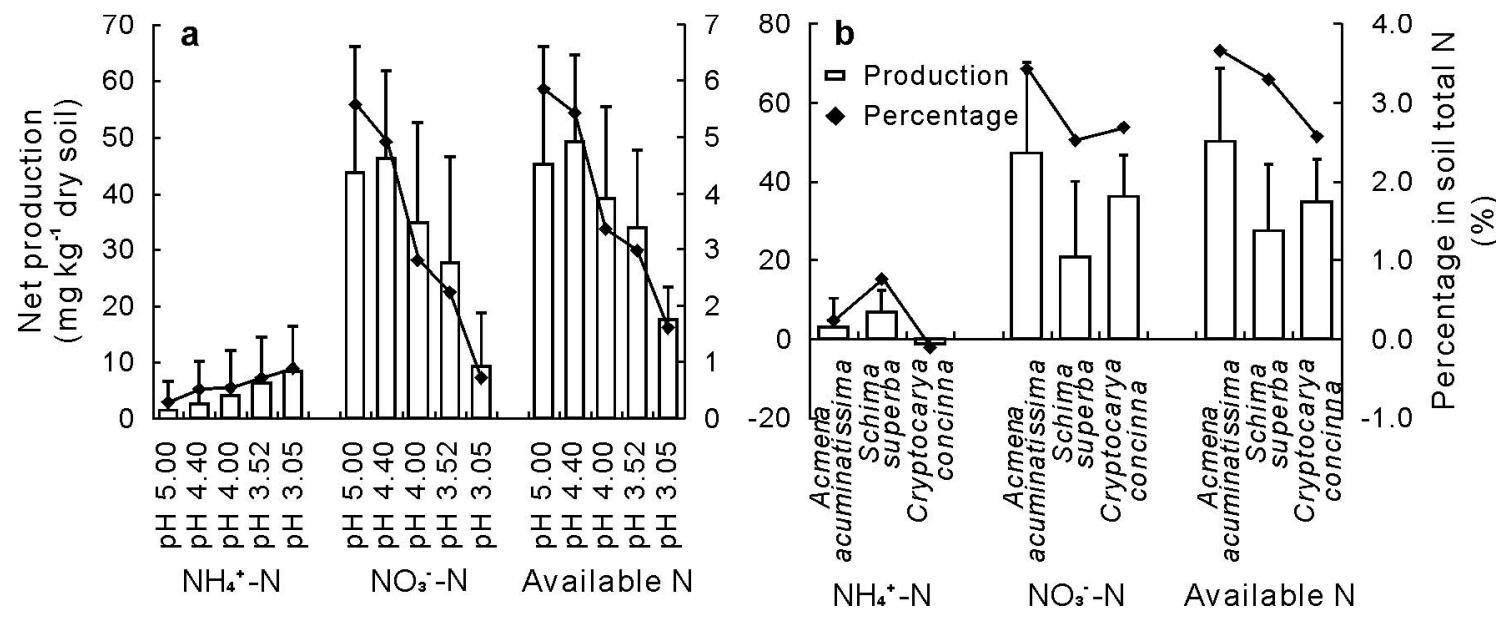

Fig. 3 Effects of simulated acid rain with different $\mathrm{pH}$ compared to the control with $\mathrm{pH} 5.00$ lake water $(n=16)(\mathrm{a})$ and wood species $(n=20)$ (b) on net productions of $\mathrm{NH}_{4}^{+}-\mathrm{N}, \mathrm{NO}_{3}^{-}-\mathrm{N}$, and available $\mathrm{N}$ and their percentages in soil total $\mathrm{N}$ after soil incubation at $25^{\circ} \mathrm{C}$. Data are mean \pm standard deviation.

\section{TABLE III}

Percentages of net $\mathrm{NH}_{4}^{+}-\mathrm{N}$ production in net available $\mathrm{N}$ production in the soils of the control with pH 5.00 lake water and the different $\mathrm{pH}$ simulated acid rain $(\mathrm{SAR})$ treatments $(n=16)$ after incubation at $25{ }^{\circ} \mathrm{C}$ and that under different seedling species $(n=20)$ from the monsoon evergreen broadleaf forest

\begin{tabular}{|c|c|c|c|c|c|c|c|}
\hline \multicolumn{5}{|l|}{ Treatment } & \multicolumn{3}{|l|}{ Species } \\
\hline $\begin{array}{l}\text { Control } \\
(\mathrm{pH} \mathrm{5.00)}\end{array}$ & $\begin{array}{l}\mathrm{pH} 4.40 \\
\mathrm{SAR}\end{array}$ & $\begin{array}{l}\mathrm{pH} 4.00 \\
\mathrm{SAR}\end{array}$ & $\begin{array}{l}\mathrm{pH} 3.52 \\
\text { SAR }\end{array}$ & $\begin{array}{l}\mathrm{pH} 3.05 \\
\text { SAR }\end{array}$ & $\begin{array}{l}\text { Acmena } \\
\text { acuminatissima }\end{array}$ & $\begin{array}{l}\text { Schima } \\
\text { superb }\end{array}$ & $\begin{array}{l}\text { Cryptocarya } \\
\text { concinna }\end{array}$ \\
\hline 6.78 & 4.67 & 13.89 & 28.14 & 54.07 & 11.10 & 39.11 & -4.90 \\
\hline
\end{tabular}

Cumulative $\mathrm{N}_{2} \mathrm{O}$ production from the soil of the control was significantly $(P \leq 0.05)$ less than that from the soils treated with $\mathrm{pH} 3.52$ and $\mathrm{pH} 3.05 \mathrm{SAR}(P \leq 0.05)$ in the first $5 \mathrm{~d}$, and thereafter higher than that from all the soils treated with SAR. The cumulative $\mathrm{N}_{2} \mathrm{O}$ production from the soils treated with $\mathrm{pH} 4.40$ and $\mathrm{pH} 4.00 \mathrm{SAR}$ was also significantly $(P \leq 0.05)$ less than that from the soil treated with pH 3.52 SAR before $20 \mathrm{~d}$, and thereafter less than that from the soils treated with $\mathrm{pH} 3.52$ and $\mathrm{pH}$ 3.05 SAR $(P \leq 0.05)$ (Fig. 4a). The cumulative $\mathrm{N}_{2} \mathrm{O}$ production tended to increase with the decrease in SAR pH. There was no significant difference in soil $\mathrm{N}_{2} \mathrm{O}$ production among the species (Fig. 4b).

Relationships of soil properties with the parameters of $C$ and $N$ mineralization

Both cumulative $\mathrm{CO}_{2}-\mathrm{C}$ and $\mathrm{CH}_{4}$ productions were not significantly correlated with soil $\mathrm{pH}$ after acid rain treatment (Table IV). The cumulative $\mathrm{CO}_{2}$-C production was significantly positively correlated with soil organic $\mathrm{C}(P \leq 0.01)$ and total $\mathrm{N}(P \leq 0.05)$, but significantly negatively correlated with the available $\mathrm{N}$ content $(P \leq 0.01)$. The net available $\mathrm{N}$ production was positively related to soil $\mathrm{pH}$, active $\mathrm{C}$, organic $\mathrm{C}, \mathrm{NO}_{3}^{-}-\mathrm{N}$, and total $\mathrm{C} / \mathrm{N}$ ratio, and negatively related to the $\mathrm{NH}_{4}^{+}-\mathrm{N}$ content, but not to total $\mathrm{N}$ and available $\mathrm{N}$ in soil. The soil $\mathrm{NO}_{3}^{-}-\mathrm{N}$ was significantly and negatively correlated with the 
cumulative $\mathrm{N}_{2} \mathrm{O}$ production $(P \leq 0.01)$ as well as the emission of $\mathrm{N}_{2} \mathrm{O}$ in the first five days $(P \leq 0.05)$. The soil $\mathrm{pH}$ was significantly and negatively correlated with cumulative $\mathrm{N}_{2} \mathrm{O}$ production $(P \leq 0.01)$ and not with the emission of $\mathrm{N}_{2} \mathrm{O}$ in the first 5 days (Table IV).

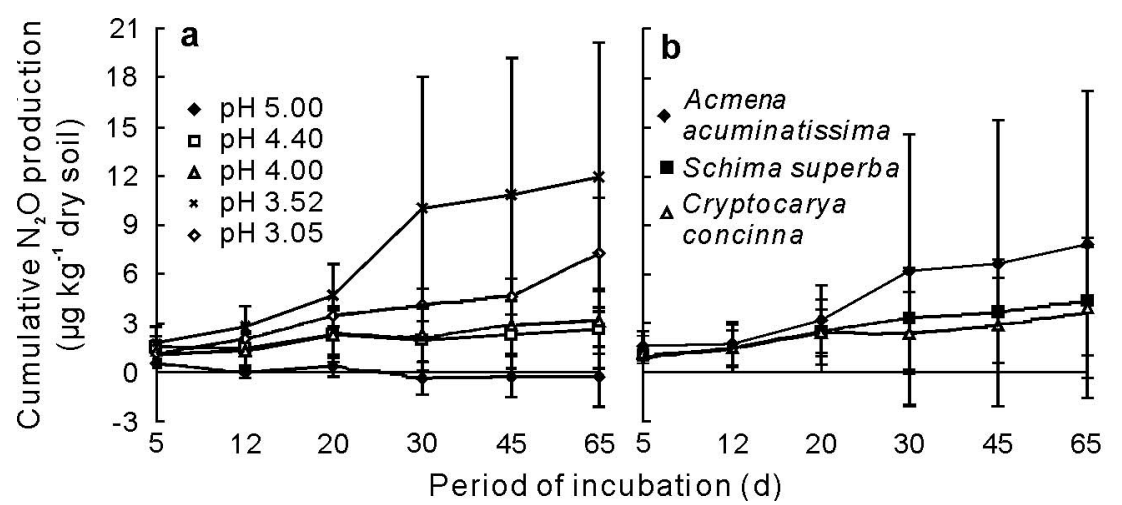

Fig. 4 Effects of simulated acid rain with different $\mathrm{pH}$ compared to the control with $\mathrm{pH} 5.00$ lake water $(n=16)(\mathrm{a})$ and wood species $(n=20)$ (b) on cumulative $\mathrm{N}_{2} \mathrm{O}$ production during soil incubation at $25{ }^{\circ} \mathrm{C}$. Data are mean \pm standard deviation.

\section{TABLE IV}

Correlation coefficients between the soil properties after acid rain treatment and the characteristic parameters of organic $\mathrm{C}$ and $\mathrm{N}$ mineralization during soil incubation

\begin{tabular}{|c|c|c|c|c|c|c|c|c|}
\hline \multirow[t]{2}{*}{ Mineralization parameter } & \multicolumn{8}{|c|}{ Soil property after acid rain treatment } \\
\hline & $\mathrm{pH}(\mathrm{KCl})$ & Active $\mathrm{C}$ & Organic $\mathrm{C}$ & $\mathrm{NH}_{4}^{+}-\mathrm{N}$ & $\mathrm{NO}_{3}^{-}-\mathrm{N}$ & Available N & Total N & Total $\mathrm{C} / \mathrm{N}$ ratio \\
\hline $\mathrm{N}_{2} \mathrm{O}$ production in the first $5 \mathrm{~d}$ & -0.14 & 0.22 & $0.27^{*}$ & -0.05 & $-0.28^{*}$ & -0.23 & 0.25 & 0.01 \\
\hline Cumulative $\mathrm{CO}_{2}-\mathrm{C}$ production & -0.05 & 0.19 & $0.38 * *$ & $-0.31^{* *}$ & $-0.26^{*}$ & $-0.42^{* *}$ & $0.29 *$ & 0.22 \\
\hline Cumulative $\mathrm{CH}_{4}$ production & -0.18 & $-0.60 * *$ & $-0.55^{* *}$ & $0.43^{* *}$ & $-0.59^{* *}$ & 0.03 & $-0.44^{* *}$ & -0.20 \\
\hline Cumulative $\mathrm{N}_{2} \mathrm{O}$ production & $-0.40^{* *}$ & 0.09 & 0.17 & 0.19 & $-0.40^{* *}$ & -0.09 & 0.23 & -0.10 \\
\hline Net $\mathrm{NO}_{3}^{-}-\mathrm{N}$ production & $0.32^{* *}$ & $0.46^{* *}$ & $0.49^{* *}$ & $-0.42^{* *}$ & $0.38^{* *}$ & -0.13 & $0.31^{* *}$ & $0.37^{* *}$ \\
\hline Net available $\mathrm{N}$ production & $0.32^{* *}$ & $0.31^{* *}$ & $0.36^{* *}$ & $-0.38^{* *}$ & $0.30^{* *}$ & -0.15 & 0.18 & $0.38^{* *}$ \\
\hline
\end{tabular}

*, **Significant at $P \leq 0.05$ and $P \leq 0.01$, respectively.

\section{DISCUSSION}

\section{Soil properties and mineralization of $C$ and $N$}

The results of this study suggested that acid rain (deposition) had a strong effect on the mineralization of soil $\mathrm{C}$ and $\mathrm{N}$. The original soil $\mathrm{pH}$ did not explain the differences in cumulative $\mathrm{CO}_{2}-\mathrm{C}$ and $\mathrm{CH}_{4}$ productions among the treatments; that is, that original $\mathrm{pH}$ of the soil played a minimum role in mineralization. The changes of soil $\mathrm{pH}$ with the treatments of SAR of decreasing pH (Table II) were not consistent with the cumulative productions of $\mathrm{CO}_{2}-\mathrm{C}$ (Fig. 1a) and $\mathrm{CH}_{4}$ (Fig. 2a) at day 65. Neither was significantly correlated with soil $\mathrm{pH}$ (Table IV).

The relationships between the 65 - $\mathrm{d}$ cumulative $\mathrm{CO}_{2}-\mathrm{C}$ production and the soil properties (Table IV) implied that the release of soil $\mathrm{CO}_{2}$ could be promoted by soil organic $\mathrm{C}(P \leq 0.01)$ and total $\mathrm{N}$ $(P \leq 0.05)$, but it could be inhibited by the available $\mathrm{N}$ content $(P \leq 0.01)$. Additionally, $\mathrm{C}$ and $\mathrm{N}$ status, but not soil $\mathrm{pH}$, influenced the bacterial activities (methanotrophy) in oxidizing $\mathrm{CH}_{4}$ in these acidic soils. These indicated that acid rain could influence the mineralization of organic $\mathrm{C}$ in acid soils by changing factors such as soil organic $\mathrm{C}$ and $\mathrm{N}$ status, rather than reducing soil $\mathrm{pH}$ alone. This finding is consistent with the observations by Bradford et al. (2001), who concluded that a single addition of $\mathrm{HNO}_{3}$ or $\mathrm{H}_{2} \mathrm{SO}_{4}$ at equivalent $\mathrm{H}^{+}$concentrations had different impacts on $\mathrm{CO}_{2}$ production and net $\mathrm{CH}_{4}$ oxidation of soil cores. Possible explanations for our observation are as follows. Firstly, the soils used in 
this study had a very low $\mathrm{pH}$ (Table I), and a small change of $\mathrm{pH}$ caused by acid rain had a minimum effect on the microbial community in the soil (Bååth and Anderson, 2003). Secondly, the microbial community might have adapted to the chronic acid rain conditions during the 42-month experiment (Blagodatskaya and Anderson, 1999; Pennanen et al., 1998). Finally, the chronic acid rain condition had a strong effect on the soil chemical properties, such as nutrient supply (Liu et al., 2004).

In contrast to $\mathrm{C}$ mineralization, the net available $\mathrm{N}$ production was positively related to soil $\mathrm{pH}$, active $\mathrm{C}$, organic $\mathrm{C}, \mathrm{NO}_{3}^{-}-\mathrm{N}$, and total $\mathrm{C} / \mathrm{N}$ ratio, and negatively related to the $\mathrm{NH}_{4}^{+}-\mathrm{N}$ content, but not to total $\mathrm{N}$ and available $\mathrm{N}$ in soil (Table IV), implying that the influence of acid deposition upon the mineralization of organic $\mathrm{N}$ was related to soil $\mathrm{pH}$ value, although the way in which soil $\mathrm{pH}$ alters the rates of organic $\mathrm{N}$ mineralization has not been well documented (Curtin et al., 1998). However, the decrease in the total $\mathrm{C} / \mathrm{N}$ ratio with the treatments of SAR showed that soil total $\mathrm{N}$ was correspondingly enriched, which implicated the occurrence of microbial $\mathrm{N}$ assimilation followed by the incorporation of $\mathrm{N}$ in SOM (Sjöberg and Persson, 1998). No significant correlation between the net production of available $\mathrm{N}$ and soil total $\mathrm{N}$ implicated that the substantial quantities of $\mathrm{N}$ were incorporated into the stable organic pool that was not readily susceptible to microbial remineralization (Kaye et al., 2002). The increase of stable organic $\mathrm{N}$ pool did not increase the net available $\mathrm{N}$ production during the short-term incubation (Updegraff et al., 1995). It seemed that the decrease of organic N quality associated with the $\mathrm{pH}$ decline caused by acid rain directly influenced the organic $\mathrm{N}$ mineralization.

The percentage of net $\mathrm{NH}_{4}^{+}-\mathrm{N}$ production in the net available $\mathrm{N}$ production ranged from $4.67 \%$ to $54.07 \%$ (Table III), so the net production of $\mathrm{NO}_{3}^{-}-\mathrm{N}$ in the net available $\mathrm{N}$ production ranged from $45.93 \%$ to $93.2 \%$, which suggests that most of $\mathrm{NH}_{4}^{+}-\mathrm{N}$ from mineralization was eventually transformed into $\mathrm{NO}_{3}^{-}-\mathrm{N}$ by nitrification. Acid deposition reduced the net production of $\mathrm{NO}_{3}^{-}-\mathrm{N}$ (Fig. 3). One possible explanation is that the decrease in the supply of $\mathrm{NH}_{4}^{+}-\mathrm{N}$ affected nitrification (Montagnini and Buschbcher, 1989; Robertson, 1984). Acid deposition reduced the supply of $\mathrm{NH}_{4}^{+}-\mathrm{N}$ (the net available $\mathrm{N}$ production) from mineralization (Fig. 3). Because the net $\mathrm{NO}_{3}^{-}-\mathrm{N}$ production was significantly $(P \leq 0.01)$ and positively correlated with soil $\mathrm{pH}$ (Table IV), another possible explanation is that the decrease in soil $\mathrm{pH}$ inhibited the growth of nitrifying bacteria (Keeney, 1980). Although nitrification occurs in soil with low $\mathrm{pH}$ (Martikainen and Boer, 1993), the rate is generally very low when the soil $\mathrm{pH}$ is lower than 6.0 (Alexander, 1977). This explained why $\mathrm{NH}_{4}^{+}-\mathrm{N}$ became the major form of the available $\mathrm{N}$ in the soils after being treated with SAR (Table II).

The treatments of simulated acid rain with decreasing $\mathrm{pH}$ increased the cumulative $\mathrm{N}_{2} \mathrm{O}$ production (Fig. 4a). This was consistent with the results of several other studies (Šimek and Cooper, 2002). The emission of $\mathrm{N}_{2} \mathrm{O}$ was mainly from a biological process, such as nitrification and denitrification (Robertson and Tiedje, 1987). Simek et al. (2002) suggested that denitrification was the major cause of $\mathrm{N}_{2} \mathrm{O}$ production. However, in acidic soils, the emission of $\mathrm{N}_{2} \mathrm{O}$ was mainly from the nitrification of $\mathrm{NH}_{4}^{+}-\mathrm{N}$ (Martikainen and Boer, 1993; Martikainen et al., 1993). In this study, we were not sure how $\mathrm{N}_{2} \mathrm{O}$ was produced. The change of the net $\mathrm{NO}_{3}^{-}-\mathrm{N}$ production with the SAR treatments (Fig 3a) was opposite to the cumulative $\mathrm{N}_{2} \mathrm{O}$ production (Fig. 4a), and the net $\mathrm{NO}_{3}^{-}-\mathrm{N}$ production was not significantly correlated with the cumulative $\mathrm{N}_{2} \mathrm{O}$ production $\left(R^{2}=-0.07, P \leq 0.56\right)$. This implied that the emission of $\mathrm{N}_{2} \mathrm{O}$ did not result from nitrification. However, the soil $\mathrm{NO}_{3}^{-}-\mathrm{N}$ was significantly and negatively correlated with the cumulative $\mathrm{N}_{2} \mathrm{O}$ production $(P \leq 0.01)$ as well as the emission rate of $\mathrm{N}_{2} \mathrm{O}$ in the first five days $(P \leq 0.05)$ (Table IV). This suggested that the emission of $\mathrm{N}_{2} \mathrm{O}$ did not result from denitrification either. The soil $\mathrm{pH}$ was significantly and negatively correlated with cumulative $\mathrm{N}_{2} \mathrm{O}$ production $(P \leq 0.01$,$) but not with the emission rate of \mathrm{N}_{2} \mathrm{O}$ in the first 5 days (Table IV), and this meant that there was no direct relationship between soil $\mathrm{pH}$ and $\mathrm{N}_{2} \mathrm{O}$ emission (Šimek and Cooper, 2002). The correlation analysis also showed that the soil properties did not have any role in controlling the emission of $\mathrm{N}_{2} \mathrm{O}$. The factors that induced the differences in the emission of $\mathrm{N}_{2} \mathrm{O}$ seemed to be very complicated and require further investigation.

No significant correlation of cumulative $\mathrm{CO}_{2}$-C production with the net production of available $\mathrm{N}$ 
(Table VI) indicated that the mineralized $\mathrm{C}$ in the soil was not covalently bound to the mineralized $\mathrm{N}$ in the soil. The controlling factors affected these two processes in different manners. Hart et al. (1994) reported that gross rates of $\mathrm{N}$ transformation could closely vary with the release of $\mathrm{CO}_{2}$ during long-term incubations, but the net $\mathrm{N}$ mineralization rates are poorly correlated with the gross $\mathrm{N}$ transformation rates. The fact that the estimates of the $\mathrm{N}$ mineralization are net rate, whereas the estimates of the $\mathrm{C}$ mineralization are gross rate, could be used to explain the poor relationship between the mineralization of N and C (Giardina et al., 2001; Xue et al., 2003). Therefore, the determination of gross N mineralization rate with acid deposition is required to gain insight into the relationship between $\mathrm{C}$ mineralization and $\mathrm{N}$ mineralization.

\section{Tree species and mineralization of $C$ and $N$}

The mineralization rates of soil $\mathrm{C}$ in the pine-dominated soils exceeded those in the aspen-dominated soils, but the net $\mathrm{N}$ mineralization rates were not related to the species (Giardina et al., 2001). The results of this study suggested that both cumulative $\mathrm{CO}_{2}-\mathrm{C}$ production (Fig. $1 \mathrm{~b}$ ) and net available $\mathrm{N}$ production (Fig. 3b) of the soils under A. acuminatissima were significantly higher $(P \leq 0.05)$ than those under $S$. superba and $C$. concinna. The difference might not necessarily reflect the litter quality of these species because the litter quality was not always a good indicator of the species differences in the mineralization of soil C and N (Giardina et al., 2001). Also, the species differences in soil properties (Table II) were not completely consistent with the species differences in cumulative $\mathrm{CO}_{2}-\mathrm{C}$ production (Fig. 1b) and net available $\mathrm{N}$ production (Fig. 3b). For example, there was no difference in soil total C/N ratio among species, whereas the active $\mathrm{C}$, organic $\mathrm{C}$, and total $\mathrm{N}$ in the soils under A. acuminatissima and $C$. concinna were significantly higher than those under $S$. superba (Table II). However, the influence of species on the composition of soil microbial communities could explain those differences. Giardina et al. (2001) showed that, although quality of aspen litter was higher than that of pine litter, the pine soil released more $\mathrm{CO}_{2}-\mathrm{C}$ than the aspen soil because the pine soil $\mathrm{C}$ supported microbial communities with a higher ratio of active fungi to active bacteria. Therefore, the composition of soil microbial communities needs to be explored to gain insight into the relationship between species and soil mineralization.

\section{REFERENCES}

Alexander, M. 1977. Introduction to Soil Microbiology. John Wiley \& Sons, New York. 467pp.

Bååth, E. and Anderson, T. H. 2003. Comparison of soil fungal/bacterial ratios in a pH gradient using physiological and PLFA-based techniques. Soil Biol. Biochem. 35: 955-963.

Beets, P. N., Oliver, G. R. and Clinton, P. W. 2002. Soil carbon protection in podocarp/hardwood forest, and effects of conversion to pasture and exotic pine forest. Environ. Pollut. 116: 63-73.

Berggren, D. and Mulder, J. 1995. The role of organic matter in controlling aluminum solubility in acidic mineral soil horizons. Geochimi. Cosmochimi. Acta. 59(20): 4167-4180.

Blagodatskaya, E. V. and Anderson, T. H. 1999. Adaptive responses of soil microbial communities under experimental acid stress in controlled laboratory studies. Appl. Soil Ecol. 11: 207-216.

Bradford, M. A., Ineson, P., Wookey, P. A. and Lappin-Scott, H. M. 2001. The effect of acid nitrogen and acid sulphur deposition on $\mathrm{CH}_{4}$ oxidization in a forest soil: a laboratory study. Soil Bio. Biochem. 33: $1695-1702$.

Brown, S., Lenart, M. T., Mo, J. M. and Kong, G. H. 1995. Structure and organic matter dynamics of a human-impacted pine forest in a MAB reserve of subtropical China. Biotropica. 27: 276-289.

Burton, A. J., Pregitzer, K. S., Crawford, J. N., Zogg, G. P. and Zak, D. R. 2004. Simulated chronic NO $3{ }_{3}^{-}$deposition reduces soil respiration in northern hardwood forests. Glob. Change Biol. 10: 1080-1091.

Chandini, M., Thirukkumaran, M. and Morrison, I. 1996. Impact of simulated acid rain on microbial respiration, biomass, and metabolic quotient in a mature sugar maple Acer saccharum forest floor. Can. J. For. Res. 26: $1446-1453$.

Cleveland, C. C., Townsend, A. R. and Schmidt, S. K. 2002. Phosphorus limitation of microbial processes in moist tropical forests: Evidence from short-term laboratory incubations and field studies. Ecosystem. 5: 680-691.

Cogbill, C. V. and Likens, G. E. 1974. Acid precipitation in the northeastern United States. Water Air Soil Poll. 10(6): $133-1137$.

Curtin, D., Campbell, C. A. and Jalil, A. 1998. Effects of acidity on mineralization: pH-dependence of organic matter mineralization in weakly acidic soils. Soil. Biol. Biochem. 30(1): 57-64. 
Derome, J. and Lindroos, A. J. 1998. Effects of heavy metal contamination on macronutrient availability and acidification parameters in forest soil in the vicinity of the Harjavlta Cu-Ni smelter, SW Finland. Environ. Pollut. 99: 225-232.

Ellis, S., Howe, M. T., Goulding, K. W. T., Mugglestone, M. A. and Dendooven, L. 1998. Carbon and nitrogen dynamics in a grassland soil with varying $\mathrm{pH}$ : Effect of $\mathrm{pH}$ on the denitrification potential and dynamics of the reduction enzymes. Soil Biol. Biochem. 30(3): 359-367.

Giardina, C. P., Ryan, M. G., Hubbard, R. M. and Binkley, D. 2001. Tree species and soil textural controls on carbon and nitrogen mineralization rates. Soil Sci. Soc. Am. J. 65: 1272-1279.

Hagedorn, F., Maurer, S., Egli, P., Blaser, P., Bucher, J. B. and Siegwolf, R. 2001. Carbon sequestration in forest soils: effects of soil type, atmospheric $\mathrm{CO}_{2}$ enrichment, and $\mathrm{N}$ deposition. Eur. J. Soil Sci. 52: 619-628.

Hart, S. C., Nason, G. E., Myrold, D. D. and Perry, D. A. 1994. Dynamics of gross nitrogen transformations in an old-growth forest: the carbon connection. Ecology. 75: 880-891.

Haynes, R. J. and Swift, R. S. 1988. Effects of lime and phosphate additions on changes in enzyme activities, microbial biomass and levels of extractable nitrogen, sulphur and phosphorus in an acid soil. Biol. Fert. Soils. 6: 153-158.

Hettelingh, J. P., Sverdrup, H. and Zhao, D. 1995. Deriving critical loads for Asia. Water Air Soil Poll. 85: $2565-2570$.

Huang, Z. F. and Fan, Z. G. 1982. The climate of Dinghu Mountain. Trop. Subtrop. Forest Ecosyst. (in Chinese). 1: $11-23$.

Johnson, D. W. 1995. Role of carbon in the cycling of other nutrients in forested ecosystems. In McFee, W. W. and Kelly, J. M. (eds.) Carbon Forms and Functions in Forest soils. SSSA, Madison, WI. pp. 299-328.

Karajick, K. 2001. Long-term data show lingering effecters from acid rain. Science. 292: 195-196.

Kato, N. 1996. Analysis of structure of energy consumption and dynamics of emission of atmospheric species related to the global environment change $\left(\mathrm{SO}_{2}, \mathrm{NO}_{X}\right.$, and $\left.\mathrm{CO}_{2}\right)$ in Asia. Atmos. Environ. 30: 757-785.

Kaye, J., Barrett, J. and Burke, I. 2002. Stable nitrogen and carbon pools in grassland soils of variable texture and carbon content. Ecosystems. 5: 461-471.

Keeney, D. R. 1980. Prediction of soil nitrogen availability in forest ecosystems: A literature review. Forest Sci. 26: $159-171$.

Lacaux, J. P., Servant, J. and Baudet, J. G. R. 1987. Acid rain in the tropical forest of the Ivory Coast. Atmos. Environ. 21(12): 2643-2647.

Lal, R. 2001. The potential of soil carbon sequestration in forest ecosystems to mitigate the greenhouse effect. In Lal, R. (ed.) Soil Carbon Sequestration and the Greenhouse Effect. Soil Science Society of America (SSSA) Special Publication No. 57. SSSA, Madison, WI. pp. 137-154.

Lee, K. and Jose, S. 2003. Soil respiration, fine root production, and microbial biomass in cottonwood and loblolly pine plantations along a nitrogen fertilization gradient. Forest Ecol. Manag. 185: 263-273.

Liu, G. S. (editor-in-chief). 1996. Soil Physical and Chemical Analysis and Description of Soil Profiles (in Chinese). China Standards Press, Beijing. 266pp.

Liu, J. X., Zhou, G. Y. and Luo, Y. 2004. The cumulative effects of simulated acid rain on the soil chemistry in monsoon evergreen broad-leaved forest at Dinghushan. Environ. Sci. (in Chinese). 25(5): 158-168.

Makarov, M. I. and Kiseleva, V. V. 1995. Acidification and nutrient imbalance in forest soils subjected to nitrogen deposition. Water Air Soil Poll. 85: 1137-1 142.

Martikainen, P. J. and Boer, W. D. 1993. Nitrous oxide production and nitrification in acidic soil from a Dutch coniferous forest. Soil Biol. Biochem. 25: 343-347.

Martikainen, P. J., Lehtonen, M., Lång, K., Boer, W. D. and Ferm, A. 1993. Nitrification and nitrous oxide production potentials in aerobic soil samples from the soil profile of a Finnish coniferous site receiving high ammonium deposition. FEMS Microbiol Ecol. 13(2): 113-121.

Michopoulos, P. 1999. Lead migration in some acid forest soils under Beech in Greece. J. Environ. Qual. 28: 1702-1708.

Mo, J. M., Brown, S., Peng, S. L. and Kong, G. H. 2003. Nitrogen availability in disturbed, rehabilitated and mature forests of tropical China. Forest Ecol. Manag. 175: 573-583.

Montagnini, F. and Buschbcher, R. 1989. Nitrification rates in two undisturbed tropical rain forests and three slash-andburn sites of the Venezuelan Amazon. Biotropica. 21(1): 9-14.

Motavalli, P. P., Palm, C. A., Parton, W. J., Elliott, E. T. and Frey, S. D. 1995. Soil pH and organic C dynamics in tropical forest soils: Evidence from laboratory and simulation studies. Soil Biol. Biochem. 27(2): 1589-1599.

Nierop, K. G. J. and Vertraten, J. M. 2003. Organic matter formation in sandy subsurface horizons of Dutch coastal dunes in relation to soil acidification. Org. Geochem. 34: 599-613.

Nodar, R., Acea, M. J. and Carballas, T. 1992. Microbiological response to $\mathrm{Ca}(\mathrm{OH})_{2}$ treatments in a forest soil. FEMS Microbiol. Ecol. 86: 213-219.

Oades, J. M. 1988. The retention of organic matter in soils. Biogeochemistry. 5: 35-70.

Pennanen, T. 2001. Microbial communities in boreal coniferous forest humus exposed to heavy metals and changes in soil $\mathrm{pH}$ - a summary of the use of phospholipid fatty acids. Geoderma. 100: 91-126.

Pennanen, T., Perkiömäki, J., Kiikkiletä, O., Vanhala, P., Neuvonen, S. and Fritze, H. 1998. Prolonged, simulated acid rain and heavy metal deposition: separated and combined effects on forest soil microbial community structure. FEMS Microbiol Ecol. 27: 291-300.

Robertson, G. P. and Tiedje, J. M. 1987. Nitrous oxide sources in aerobic soils: nitrification, denitrification and other biological processes. Soil Biol. Biochem. 19: 187-193. 
Robertson, G. P. 1984. Nitrification and nitrogen mineralization in a lowland forest succession in Costa Rica, Central America. Oecologia. 64: 99-104.

Rodhe, H., Galloway, J. and Zhao, D. 1992. Acidification in Southeast Asia-Prospects for the coming decades. Ambio (in Chinese). 21: 148-150.

Schwesig, D., Kalbitz, K. and Matzner, E. 2003. Effects of aluminium on the mineralization of dissolved organic carbon derived from forest floors. Eur. J. Soil Sci. 54: 311-322.

Seip, H. M., Aagaard, P. and Angell, V. 1999. Acidification in China: Assessment based on studies at forested sites from Chongqing to Guangzhou. Ambio (in Chinese). 28(6): 524-529.

Shah, Z., Adams, W. A. and Haven, C. D. 1990. Composition and activity of the microbial population in an acidic upland soil and effects of liming. Soil Biol. Biochem. 22: 257-263.

Šimek, M. and Cooper, J. E. 2002. The influence of soil pH on denitrification-progress towards the understanding of this interaction over the last 50 years. Eur. J. Soil Sci. 53: 345-354.

Šimek, M., Jíśová, L. and Hopkins, D. W. 2002. What is the so-called optimum pH for denitrification in soil? Soil Biol. Biochem. 34: $1227-1234$.

Sjöberg, R. M. and Persson, T. 1998. Turnover of carbon and nitrogen in coniferous forest soils of different N-status and under different ${ }^{15} \mathrm{NH}_{4}-\mathrm{N}$ application rate. Environ. Pollut. 102(S1): 385-393.

Spain, A. V. 1990. Influence of environmental conditions and some soil chemical properties on the carbon and nitrogen contents of some tropical Australian rainforest soils. Aust. J. Soil Res. 28: 825-839.

Streets, D. G., Carmichael, G. R., Amann, M. and Arndt, R. L. 1999. Energy consumption and acid deposition in Northeast Asia. Ambio (in Chinese). 28: 135-143.

Tiessen, H. E., Cuevas, E. and Chacon, P. 1994. The role of soil organic matter in sustaining soil fertility. Nature. 371: $783-785$.

Updegraff, K., Pastor, J., Bridgham, S. D. and Johnston, C. A. 1995. Environmental and substrate controls over carbon and nitrogen mineralization in northern wetlands. Ecol. Appl. 5: 151-163.

van Bergen, P. F., Nott, C. J., Bull, I. D., Poulton, P. R. and Evershed, R. P. 1998. Organic geochemical studies of soils from the Rothamsted Classical Experiments-IV. Preliminary results from a study of the effect of soil pH on organic matter decay. Org. Geochem. 29(5-7): 1779-1 795.

Wang, Z. H., He, D. Q., Song, S. D., Chen, D. R. and Tu, M. Z. 1982. The vegetation of the Dinghushan Biosphere Reserve. Trop. Subtrop. Forest Ecosyst. (in Chinese). 1: 77-141.

Weier, K. L. and Gilliam, J. W. 1986. Effect of acidity on nitrogen mineralization and nitrification in Atlantic Coastal Plain soils. Soil Sci. Soc. Am. J. 50: $1210-1214$.

Weil, R. R., Islam, K. R., Stine, M. A., Gruver, J. B. and Samson-Liebig, S. E. 2003. Estimating active carbon for soil quality assessment: A simplified method for laboratory and field use. Am. J. Alternative Agr. 18(1): 3-17.

Xue, J. M., Sands, R., Clinton, P. W., Payn, T. W. and Skinner, M. F. 2003. Carbon and net nitrogen mineralization in two forest soils amended with different concentrations of biuret. Soil Biol. Biochem. 35: 855-866.

Zelles, L., Scheunert, I. and Kretzer, K. 1987. Effect of artificial irrigation, acid precipitation and liming on the microbial activity in soil of a spruce forest. Biol. Fert. Soils. 4: 137-143.

Zhou, H. C., Li, M. J., Zhou, Y. R., He, D. Q. and Huang, Y. J. 1986. The vegetation map of the Dinghushan Biosphere Reserve with reference to its illustration. Trop. Subtrop. Forest Ecosyst. (in Chinese). 4: 43-49. 